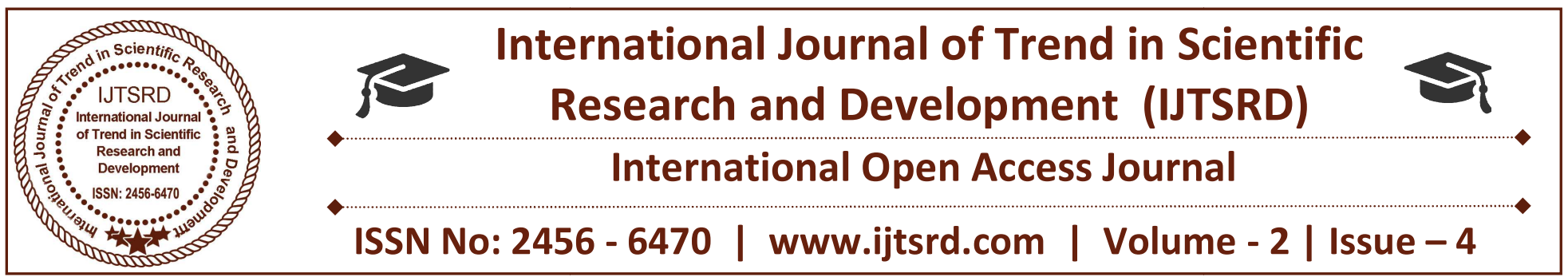

\title{
Effect of Foliar Application of Micronutrients on Growth, Yield and Quality of Tomato
}

\author{
Dr. R. Pandiyan, Dr. V. A. Sathyamurthy, Dr. L. Pugalenthi \\ Department of Vegetable Crops, Horticultural College and Research Institute, \\ Tamil Nadu Agricultural University, Coimbatore, Tamil Nadu, India
}

\section{ABSTRACT}

A field experiment was carried out to study the response of tomato to foliar application of micronutrients from 2011 to 2014 at the Department of Vegetable Crops, Horticultural College and Research Institute, Tamil Nadu Agricultural University, Coimbatore. The hybrid COTH 2 was chosen for this study. The results based on three years mean revealed that out of fourteen different treatments, Different combinations of all the micronutrients were applied in three replications. The pooled analysis revealed that among the different combinations In tomato hybrid COTH 2, spraying of mixture of all micronutrients (Boric acid@100 ppm, ZnSo4@100.ppm ,Ammonium molybdate@50 ppm. Copper sulphate@100 ppm,Ferrussulphate@ 100 ppm, Manganese sulphate@100 ppm) (3 sprays at an interval of 40 days from DAP) recorded the highest plant height $(95.7 \mathrm{~cm})$, number of fruits per plant (46.4) fruit weight $(61.9 \mathrm{~g})$, fruit yield per plot $(63.5 \mathrm{~kg})$ and highest yield of $564.1 \mathrm{q} /$ ha followed by spraying of commercial formulation (Multiplex) $(558.8 \mathrm{q} / \mathrm{ha})$. The highest $\mathrm{BC}$ ratio of 3.04 was recorded in Mixture of all treatment which was followed by spraying of Zn Sulphate@ @ 100 ppm (3.00).

Keywords: Tomato hybrid, foliar application, Micro nutrients, growth, Yield

Tomato (LycopersiconesculentumMiller, $2 \mathrm{n}=2 \mathrm{x}$ $=24$ ), popularly known as wolf apple, love of apple or Vilayatibainganis one of the most important vegetable crop, belongs to family Solanaceae, originated in tropical America and was introduced in India by the Portuguese. It is a leading vegetable crop grown across the length and breadth of country due to its wide adaptability of various agro-climatic conditions. It is equally liked by both poor and rich and is quite high in nutritive value. Micronutrients are not only essential for better growth, yield and quality but also important like other major nutrients in spite of their requirement in micro quantity. These also helps in uptake of major nutrients and also vital to the growth of plants acting as catalyst in promoting various organic reaction from cell development to respiration, photosynthesis, chlorophyll formation, enzyme activity, hormones synthesis and nitrogen fixation. Considerable research work has been done on the aspect of foliar application of micronutrient indifferent crops and the experimental results indicated not only increase in yield up to 20 per cent but also helpful to sustain crop production. Aroraet al. (1979) reported that micronutrients like boron, copper, molybdenum and zinc through foliage can also improve the vegetative growth, fruit set and yield of tomato. Working with tomato, Mallick and Muthukrishnan (1980) reported that the role of micronutrients in the "nutrient element balance" of the plant is of considerable interest

\section{MATERIALS AND METHODS}

The present investigation was carried out at the All India Co-Ordinated Vegetable Improvement Project (AICVIP) at the Department of Vegetable Crops, Horticultural College and Research Institute, Coimbatore from April, 2010 to March, 2014. Field trials were laid out in randomized block design with fourteen treatments replicated thrice. Tomato hybrids COTH 2 were taken for this study. The micronutrients viz.Boric acid @100 ppm, ZnSo4@100 ppm ,Ammoniummolybdate@50 ppm. Copper sulphate 
@ 100 ppm, Ferrussulphate@ 100 ppm, Manganese sulphate@100 ppm were sprayed individually and in combinations on tomato with three sprays at an interval of 10 days starting from 40 days after transplanting. A control without spray and commercial formulation (multiplex)@4ml/lit also included in the treatment combinations to compare the results. The experiment was laid out in RBD with three replications. 25 days old tomato seedlings raised in the pro trays were transplanted at a spacing of $75 \mathrm{x}$ $60 \mathrm{~cm}$ with the plot size of $3.0 \times 3.6 \mathrm{~m}$. The results of the three year trials were presented in the Table 1,2 and 3 and the pooled mean data are presented in Table 4.

\section{RESULTS AND DISCUSSION}

Response of tomato to foliar application of micronutrients during kharif 2011-12.The results revealed that the treatment mixture of all micronutrients recorded the highest plant height (98.8 $\mathrm{cm}$ ), fruits per plant $(47.8)$, fruit weight $(63.8 \mathrm{~g})$, fruit yield per plot $(63.8 \mathrm{~kg})$, yield per ha $(567.6 \mathrm{q})$. The highest fruits weight $64.2 \mathrm{~g}$ were recorded in mixture of all without Mn spray. Mixture of all without Fe registered the highest shelf life of 10.7 days. While, control and commercial formulation recorded the yield of 521.2 and $559.5 \mathrm{q} /$ ha respectively. Response of tomato to foliar application of micronutrients during kharif 2012-13. The results revealed that the highest plant height of $97.8 \mathrm{~cm}$ was recorded on the treatment T7 (Mixture of all) and T 8 (Mixture of all without $\mathrm{Cu}$ ). The highest number of fruits per plant (63.6) recorded in the treatment Mixture of all without $\mathrm{Mn}$ and the highest yield per plot $(63.2 \mathrm{~kg})$ and yield per ha $(562 \mathrm{q})$ recorded in the Treatment T7 (Mixture of all). The T14 (commercial formulation) registered the yield of $554 \mathrm{q} / \mathrm{ha}$ while the control recorded the yield of $516 \mathrm{q} / \mathrm{ha}$ registered the highest yield of $562 \mathrm{q} /$ ha followed by $\mathrm{T} 14$ commercial formulation (554 q/ha). The treatment T12 (Mixture of all without $\mathrm{Fe}$ ) recorded the highest shelf life of 10.60 days in ambient condition. Response of tomato to foliar application of micronutrients during kharif 201314.The highest plant height $(87.6 \mathrm{~cm})$, fruits per plant (42.4) and fruit weight $(56.4 \mathrm{~g})$ recorded in the treatment $\mathrm{T} 7$ (Mixture of all). The treatment T7 (Mixture of all) and T11 (mixture of all without $\mathrm{Cu}$ ) registered the highest yield of $497.6 \mathrm{q} / \mathrm{ha}$ followed by commercial formulation $(494.0 \mathrm{q} / \mathrm{ha})$. The treatment T12 (Mixture of all without $\mathrm{Fe}$ ) recorded the highest shelf life of 10.6 days in ambient condition. While, the control recorded the yield of $460.6 \mathrm{q} / \mathrm{ha}$. The pooled data of three years trials revealed that among the different treatment combination sprayed in the Tomato hybrid COTH 2, spraying of mixture of all micronutrients (Boric acid@100 ppm,ZnSo4@100 ppm ,Ammonium molybdate@ 50 ppm. Copper sulphate@100 ppm, Ferrussulphate@100 ppm, Manganese sulphate@ 100 ppm) (3 sprays at an interval of 40 days from DAP) recorded the highest plant height $(95.7 \mathrm{~cm})$, number of fruits per plant (46.4), fruit weight (61.9 g), fruit yield per plot (63.5 $\mathrm{kg})$ and yield/ha $(564.1 \mathrm{q})$. The treatment $\mathrm{T} 14$ (commercial formulation (Multiplex)) recorded the yield of $558.8 \mathrm{q} /$ ha. The highest $\mathrm{BC}$ ratio of 3.04 was recorded in Mixture of all treatment which was followed by spraying of Zn Sulphate@100 ppm (3.00).Boron is associated with the development of cell wall and cell differentiation and hence, helps in root elongation and shoot growth of plant. The need of boron has been emphasized earlier for normal growth of tomato plant by Johnson and Fisher (1930).All the micronutrient treatments except manganese and iron were found significantly effective in increasing fruits per plant and fruit weight $(\mathrm{g})$. Improvement in growth characters as a result of application of micronutrients might be due to the enhanced photosynthetic and other metabolic activity which leads to an increase in various plant metabolites responsible for cell division and elongation as opined by Hatwar et al. (2003). The photosynthesis enhanced in presence of zinc and boron was also reported by Rawat and Mathpal (1984). Mallick and Muthukrishnan (1979) explained that presence of zinc activates the synthesis of tryptophan, the precursor of IAA and it is responsible to stimulate plant growth. Iron plays an important role in promoting growth characters, being a component offerrodoxin, an electron transport protein and is associated with chloroplast. It helps in photosynthesis might have helped in better vegetative growth (Hazra et al., 1987). The effect of boron application was more pronounced followed by mixture of micronutrients showing an increase of 35 percent in yield over control. The yield per ha was increased with boron applications reported by Govindan (1952). Increased yield due to micronutrients application may be attributed to enhanced photosynthesis activity and increased production and accumulation of carbohydrates and favorable effect on vegetative growth and retention of flowers and fruits, which increased number of fruits per plant besides increasing the size. Similarly, the Kumbhar and Deshmukh (1993) and Bose and Tripathi(1996) 
revealed that the increased dry matter production may be attributed to greater accumulation of photosynthates by vegetative parts and fruits in tomato.

\section{CONCLUSION}

From the above study, it could be concluded, that the pooled data of three years trials revealed that among the different treatment combination sprayed in the Tomato hybrid $\mathrm{COTH} 2$, spraying of mixture of all micronutrients (Boric acid@100 ppm, ZnSo4@100 ppm,Ammoniummolybdate@50 ppm. Copper sulphate@100 ppm, Ferrussulphate@100 ppm, Manganese sulphate@ 100 ppm) (3 sprays at an interval of 40 days from DAP) recorded the highest plant height $(95.7 \mathrm{~cm})$, number of fruits per plant (46.4), fruit weight (61.9 g), fruit yield per plot (63.5 $\mathrm{kg})$ and yield/ha $(564.1 \mathrm{q})$. The treatment T14 (commercial formulation (Multiplex)) recorded the yield of $558.8 \mathrm{q} /$ ha. The highest BC ratio of 3.04 was recorded in Mixture of all treatment which was followed by spraying of Zn Sulphate @ 100 ppm (3.00).

\section{Acknowledgement}

The author has been thankful to Department of Vegetables Crops, Horticultural College and Research Institute, Tamil Nadu Agricultural University, Coimbatore, for providing the Research AssociateonAICRP-VC during the period of study.

\section{REFERENCES}

1. Arora, S.K., Pandita, M.L. and Pandey, S.C. 1979. Effect of plant growth regulator and micronutrients on the fruit set, early and total yield of tomato variety HS-102 ( $L$. esculentumMill.) during summer season. In: National Seminar On "Physiological Basis of Crop productivity and Harvesting Solar Energy in relation to Agric. Dev.' At AMU, Aligarh, p716.

2. Bose, U.S. and Tripathi S.K., 1996, Effect of micronutrients on growth, yield and quality of tomato cv. Pusa Ruby in M.P. Crop Res. 12:6166.

3. Govindan, P.R., 1952, Influence of boron on yield and content of Carbohydrates in tomato fruits. Curr. Sci., 21:14-15.

4. Hazra, P., Maity, T.K. and Mandal, A.R., 1987, Effect of foliar application of micronutrients on growth and yield of okra (Abelmoschusesculentus L). Prog. Hort., 19: 219-222.

5. Johnson, E.S. and Fisher, P.L., 1930, The essential nature of boron to the growth and fruiting of tomato. Pla. Phys. 5:387-392.

6. Kumbhar, V.S and Deshmukh S.S., 1993, Effect of soil application of ferrous sulphate on the uptake of nutrients, yield and quality of tomato Cv. Rupali. Sou. Ind. Hort., 41:144-147.

7. Mallick, M.F.R. and Muthukrishnan, C.R. (1980). Effect of micronutrient on tomato Lycopersiconesculentum Mill.). South Indian Hort., 28(1): 14-20. 
International Journal of Trend in Scientific Research and Development (IJTSRD) ISSN: 2456-6470

Table 1. Response of tomato to foliar application of micronutrients during kharif 2011-2012.

\begin{tabular}{|l|l|l|l|l|l|l|}
\hline \multicolumn{1}{|c|}{ Treatments } & $\begin{array}{c}\text { Plant } \\
\text { height } \\
(\mathbf{c m})\end{array}$ & $\begin{array}{l}\text { Fruits } \\
\text { /plant }\end{array}$ & $\begin{array}{c}\text { Fruit } \\
\text { weight } \\
(\mathrm{g})\end{array}$ & $\begin{array}{c}\text { Fruit } \\
\text { yield per } \\
\text { plot (kg) }\end{array}$ & $\begin{array}{l}\text { Yield / } \\
\text { ha }(\mathbf{q})\end{array}$ & $\begin{array}{c}\text { Shelf } \\
\text { life } \\
\text { (days) }\end{array}$ \\
\hline T0. Control (without spray) & 97 & 44.6 & 61.8 & 58.6 & 521.2 & 9.6 \\
\hline T1. Boric acid @ 100 ppm & 96.6 & 46.4 & 62.6 & 60.2 & 535.3 & 10.3 \\
\hline T2. Zinc sulphate @ 100 ppm & 97.9 & 45.9 & 62.5 & 60.9 & 542.4 & 9.5 \\
\hline T3. Ammonium molybdate @ 50 pm & 95.4 & 43.5 & 61.4 & 58.4 & 520.2 & 9.5 \\
\hline T4. Copper sulphate @ 100 ppm & 96.4 & 45.6 & 61.9 & 60 & 534.3 & 9.4 \\
\hline T5. Feroussulphate @ 100 ppm & 98.3 & 47 & 62 & 61.6 & 548.4 & 9.3 \\
\hline T6. Manganesesulphate @ 100 ppm & 97.4 & 46.4 & 62.2 & 61 & 543.4 & 9.4 \\
\hline T7. Mixture of all & 98.9 & 47.8 & 63.8 & 63.8 & 567.6 & 10.5 \\
\hline T8. Mixture of all without B & 97 & 45.1 & 62.1 & 59.3 & 528.2 & 9.5 \\
\hline T9. Mixture of all without Zn & 97.5 & 45.6 & 62.5 & 60.6 & 539.3 & 10.4 \\
\hline T10. Mixture of all without Mo & 98.7 & 47 & 63.3 & 61.8 & 550.5 & 10.6 \\
\hline T11. Mixture of all without Cu & 98.9 & 46.9 & 63.7 & 62.4 & 555.5 & 10.6 \\
\hline T12. Mixture of all without Fe & 97.9 & 45.2 & 63.2 & 60.6 & 539.3 & 10.7 \\
\hline T13. Mixture of all without Mn & 97.4 & 45.6 & 64.2 & 62.2 & 553.5 & 10.6 \\
\hline T14. Commercial formulation (Multiplex) & 98.8 & 46.5 & 63.7 & 62.8 & 559.5 & 10.5 \\
\hline CD (P=0.05) & 1.965 & 1.214 & 1.354 & 1.284 & 10.256 & 0.086 \\
\hline CV \% & 5.69 & 6.98 & 8.56 & 6.54 & 6.54 & 6 \\
\hline
\end{tabular}

Table 2. Response of tomato to foliar application of micronutrients during kharif 2012-13

\begin{tabular}{|l|l|l|l|l|l|l|}
\hline \multicolumn{1}{|c|}{ Treatments } & $\begin{array}{c}\text { Plant } \\
\text { height } \\
(\mathbf{c m})\end{array}$ & $\begin{array}{l}\text { Fruits } \\
\text { plant }\end{array}$ & $\begin{array}{c}\text { Fruit } \\
\text { weight } \\
(\mathbf{g})\end{array}$ & $\begin{array}{c}\text { Fruit } \\
\text { yield per } \\
\text { plot }(\mathrm{kg})\end{array}$ & $\begin{array}{l}\text { Yield / } \\
\text { ha }(\mathbf{q})\end{array}$ & \multicolumn{1}{|l|}{$\begin{array}{c}\text { Shelf } \\
\text { life } \\
(\mathbf{d a y s})\end{array}$} \\
\hline T0. Control (without spray) & 95.9 & 44.2 & 61.2 & 58 & 516 & 9.5 \\
\hline T1. Boric acid @ 100 ppm & 95.5 & 45.9 & 62 & 59.6 & 530 & 10.2 \\
\hline T2. Zinc sulphate @ 100 ppm & 96.8 & 45.4 & 61.9 & 60.3 & 537 & 9.4 \\
\hline T3. Ammonium molybdate @ 50 ppm & 94.4 & 43.1 & 60.8 & 57.8 & 515 & 9.4 \\
\hline T4. Copper sulphate @ 100 ppm & 95.3 & 45.1 & 61.3 & 59.4 & 529 & 9.3 \\
\hline T5. Feroussulphate @ 100 ppm & 97.2 & 46.5 & 61.4 & 61 & 543 & 9.25 \\
\hline T6. Manganese sulphate @ 100 ppm & 96.3 & 45.9 & 61.6 & 60.4 & 538 & 9.35 \\
\hline T7. Mixture of all & 97.8 & 47.3 & 63.2 & 63.2 & 562 & 10.4 \\
\hline T8. Mixture of all without B & 95.9 & 44.7 & 61.5 & 58.7 & 523 & 9.4 \\
\hline T9. Mixture of all without Zn & 96.4 & 45.1 & 61.9 & 60 & 534 & 10.3 \\
\hline T10. Mixture of all without Mo & 97.6 & 46.5 & 62.7 & 61.2 & 545 & 10.45 \\
\hline T11. Mixture of all without Cu & 97.8 & 46.4 & 63.1 & 61.8 & 550 & 10.55 \\
\hline T12. Mixture of all without Fe & 96.8 & 44.8 & 62.6 & 60 & 534 & 10.6 \\
\hline T13. Mixture of all without Mn & 96.3 & 45.1 & 63.6 & 61.6 & 548 & 10.45 \\
\hline T14. Commercial formulation (Multiplex) & 97.7 & 46 & 63.1 & 62.2 & 554 & 10.4 \\
\hline CD (P=0.05) & 1.854 & 1.071 & 1.245 & 1.201 & 12.564 & 0.085 \\
\hline CV \% & 5.05 & 6.21 & 9.28 & 6.5 & 6.5 & 4.8 \\
\hline
\end{tabular}


International Journal of Trend in Scientific Research and Development (IJTSRD) ISSN: 2456-6470

Table 3. Response of tomato to foliar application of micronutrients during kharif 2013-14

\begin{tabular}{|l|l|l|l|l|l|l|}
\hline \multicolumn{1}{|c|}{ Treatments } & $\begin{array}{c}\text { Plant } \\
\text { height } \\
(\mathrm{cm})\end{array}$ & $\begin{array}{l}\text { Fruits } \\
\text { plant }\end{array}$ & $\begin{array}{c}\text { Fruit } \\
\text { weight } \\
(\mathrm{g})\end{array}$ & $\begin{array}{c}\text { Fruit } \\
\text { yield per } \\
\text { plot }(\mathrm{kg})\end{array}$ & $\begin{array}{l}\text { Yield / } \\
\text { ha }(\mathbf{q})\end{array}$ & $\begin{array}{c}\text { Shelf } \\
\text { life } \\
(\mathbf{d a y s})\end{array}$ \\
\hline T0. Control (without spray) & 85.6 & 39.5 & 54.6 & 51.8 & 460.6 & 9.3 \\
\hline T1. Boric acid @ 100 ppm & 85.5 & 40 & 55.4 & 53.2 & 473.3 & 10.2 \\
\hline T2. Zinc sulphate @ 100 ppm & 86.4 & 40.5 & 55.3 & 53.8 & 478.9 & 9.4 \\
\hline T3. Ammonium molybdate @ 50 ppm & 84.8 & 39.6 & 54.3 & 51.6 & 459.5 & 9.3 \\
\hline T4. Copper sulphate @ 100 ppm & 85 & 40.3 & 54.7 & 53 & 471.9 & 9.5 \\
\hline T5. Feroussulphate @ 100 ppm & 86.8 & 41.5 & 54.8 & 54.5 & 485 & 9.5 \\
\hline T6. Manganese sulphate @ 100 ppm & 86.2 & 41 & 55 & 53.9 & 480 & 9.4 \\
\hline T7. Mixture of all & 87.6 & 42.4 & 56.4 & 55.9 & 497.6 & 10.5 \\
\hline T8. Mixture of all without B & 85.6 & 39.9 & 54.9 & 52.5 & 466.8 & 9.4 \\
\hline T9. Mixture of all without Zn & 86.2 & 40.3 & 55.3 & 53.6 & 476.7 & 10.4 \\
\hline T10. Mixture of all without Mo & 87.1 & 41 & 56 & 54.6 & 486.1 & 10.5 \\
\hline T11. Mixture of all without Cu & 87.3 & 41.4 & 56.3 & 55.9 & 497.6 & 10.5 \\
\hline T12. Mixture of all without Fe & 86.3 & 39.8 & 55.9 & 53.6 & 476.6 & 10.6 \\
\hline T13. Mixture of all without Mn & 86 & 40.3 & 56.8 & 55 & 489.3 & 10.5 \\
\hline T14. Commercial formulation (Multiplex) & 87 & 41.1 & 56.3 & 55.5 & 494 & 10.4 \\
\hline CD (P=0.05) & 0.932 & 0.374 & 0.244 & 0.576 & 12.639 & 0.12 \\
\hline CV \% & 5.26 & 6.13 & 6.54 & 4.31 & 4.31 & 6.48 \\
\hline
\end{tabular}

Table 4. Pooled mean of the trial on to study the response of tomato to foliar application of micronutrients during 2011-141

\begin{tabular}{|l|c|c|c|c|c|c|c|}
\hline \multicolumn{1}{|c|}{ Treatments } & $\begin{array}{c}\text { Plant } \\
\text { height(cm) } \\
\text { Plant } \\
\text { height(cm) }\end{array}$ & $\begin{array}{c}\text { Fruits } \\
\text { plant }\end{array}$ & $\begin{array}{c}\text { Fruit } \\
\text { weight } \\
(\mathrm{g})\end{array}$ & $\begin{array}{c}\text { Fruit } \\
\text { yield per } \\
\text { plot (kg) }\end{array}$ & $\begin{array}{c}\text { Yield } \\
\text { / ha } \\
(\mathbf{q})\end{array}$ & $\begin{array}{c}\text { Shelf } \\
\text { life(days) }\end{array}$ & $\begin{array}{c}\text { BC } \\
\text { ratio }\end{array}$ \\
\hline T0. Control (without spray) & 93.3 & 43.4 & 59.7 & 58.3 & 519.5 & 9.5 & 2.87 \\
\hline T1. Boric acid @ 100 ppm & 93.3 & 44.6 & 60.8 & 60.1 & 535.9 & 10.3 & 2.9 \\
\hline T2. Zinc sulphate @ 100 ppm & 94.6 & 44.4 & 60.9 & 60.9 & 543.3 & 9.5 & 3 \\
\hline $\begin{array}{l}\text { T3. Ammonium molybdate @ 50 } \\
\text { ppm }\end{array}$ & 92.4 & 42.9 & 59.6 & 58.2 & 519.9 & 9.4 & 2.74 \\
\hline T4. Copper sulphate @ 100 ppm & 93 & 44.1 & 59.9 & 59.6 & 531.6 & 9.4 & 2.8 \\
\hline T5. Feroussulphate @ 100 ppm & 95 & 45.6 & 60.3 & 61.5 & 548.9 & 9.4 & 2.99 \\
\hline T6. Manganesesulphate @ 100 ppm & 94.2 & 44.8 & 60.3 & 60.7 & 541.4 & 9.4 & 2.85 \\
\hline T7. Mixture of all & 95.7 & 46.4 & 61.9 & 63.5 & 564.1 & 10.5 & 3.04 \\
\hline T8. Mixture of all without B & 93.6 & 43.9 & 60.4 & 59.3 & 529.3 & 9.4 & 2.86 \\
\hline T9. Mixture of all without Zn & 94.3 & 44.1 & 60.8 & 60.6 & 540.8 & 10.4 & 2.96 \\
\hline T10. Mixture of all without Mo & 95.2 & 45.1 & 61 & 61 & 543.9 & 10.5 & 2.86 \\
\hline T11. Mixture of all without Cu & 95.4 & 45.2 & 61.5 & 61.9 & 552.5 & 10.6 & 2.91 \\
\hline T12. Mixture of all without Fe & 94.5 & 44.2 & 61.2 & 60.6 & 540.7 & 10.7 & 2.95 \\
\hline T13. Mixture of all without Mn & 94.2 & 44.2 & 61.9 & 61.4 & 547.2 & 10.5 & 2.86 \\
\hline $\begin{array}{l}\text { T14. Commercial formulation } \\
\text { (Multiplex) }\end{array}$ & 95.4 & 45.1 & 61.7 & 62.5 & 558.8 & 10.4 & 2.99 \\
\hline CD (P=0.05) & 1.256 & 0.458 & 0.364 & 0.845 & 13.645 & 0.185 & \\
\hline CV \% & 6.36 & 6.85 & 6.74 & 4.95 & 4.36 & 7.25 & \\
\hline
\end{tabular}

